5. Vasiutynska, Yu. O. 2012. Shliakhy rozvytku molochnoi haluzi Ukrainy - Ways of development of the dairy industry of Ukraine. Ekonomika APK-Economy of the agroindustrial complex. 1:166-171 (in Ukrainian).

6. Prohnoz: svitove vyrobnytstvo moloka - Forecast: global milk production [Elektronnyy resurs]. - Access mode : http:// agroportal.ua-/ua/news/mir/prognoz-mirovoe-proizvodstvo-molokaneskolko-vyrastet/ (in Russian).

7. Prohnoz rozvytku tvarynnytstva u 2017 rotsi - Forecast of livestock development in 2017 [Elektronnyy resurs]. - Access mode : http:// www.avm-ua.org/uk/post/prognoz-rozvitku-tvarinnictva-u-2017-roci?milkua=1 (in Ukrainian).

8. Tivonchuk, S. V., Y. O. Tivonchuk, and T. P. Pavlocka. 2017. Rozvytok rynku vyrobnytstva moloka v Ukraini v konteksti yevrointehratsiinykh protsesiv - Development of the milk production market in Ukraine in the context of European integration processes. Ekonomika APK - Economy of the agroindustrial complex. 4:25-31 (in Ukrainian).

9. 2018. Derzhavna sluzhba statystyky Ukrainy - State Statisstics Service of Ukraine [Elektronnyy resurs]. - Regim dostupu: http://www.ukrstat.gov.ua (in Ukrainian).

10. Prokopenko, O. M. 2013. Tvarinnictvo Ukraini - Animal production of Ukraine. Statistichniy zbirnik - Statistikal yearbook. 26:156 (in Ukrainian).

11. Osnovy statystyky silskoho hospodarstva - Basics of agricultural statistics [Elektronniy resurs]. - Access mode : http://ubooks.com.ua/books/000239/inx33.php.

12. Mamchur, V. A. 2017. Instytutsiino-ekonomichnyi mekhanizm rozvytku rynku moloka i molokoproduktiv - institutional and economic mechanism of the dairy product market. Ekonomika APK - Economy of the agroindustrial complex. 4:41-49 (in Ukrainian).

13. Tkachuk, S. P. 2015. Rozvytok rynku moloka ta molokoproduktiv Ukrainy v umovakh yoho adaptatsii do vymoh Yevropeiskoho Soiuzu - Development of the milk and milk products market of Ukraine in conditions of its adaptation to the requirements of the European Union. Bioresursi i prirodokoristuvannya - Bioresources and nature management. 1/2:145-151 (in Ukrainian).

14. Krysanov, D. F. 2016. Intehratsiia ahrarnoho sektoru Ukrainy do vnutrishnoho rynku Yevropeiskoho Soiuzu - Integration of the agrarian sector of Ukraine in the internal market of European Union. Ekonomika APK - Economy of the agroindustrial complex. 9:68-78 (in Ukrainian).

15. Mamchur, V. A. 2016. Intytutsionalnyi kapital yak konstruktor rozvytku ahrarnoho rynku Institutional capital as a constructor of agrarian market development. Ekonomika APK - Economy of the agroindustrial complex. 5:93 (in Ukrainian).

УДК 636.32/.38.033.06

\title{
МЯСНАЯ ПРОДУКТИВНОСТЬ ЦИГАЙСКИХ ОВЕЦ И ИХ ПОМЕСЕЙ С ПОРОДОЙ БЕНТХАЙМЕР
}

\section{П. И. ЛЮЦКАНОВ, О. А. МАШНЕР}

Научно-практический институт биотехнологий в зоотехнии и ветеринарной медицине (Максимовка, Молдова)

liutskanov@mail.ru

Статья посвящена изучению мясной продуктивности помесных баранчиков первого поколения ㅇигайх $\precsim$ Бентхаймер в сравнении с ичигайскими местной популячии. Проведено контрольное вырашивание баранчиков с последуюшим убоем в 6-месячном возрасте. Взяты промеры туш и рассчитаны индексы. Для расчета коэффициента мясности и получения средней пробы мяса с иелью изучения его химического состава была проведена сортовая разрубка с обвалкой правых полутуш от всех забитых баранчиков. $У$ помесных баранчиков 
фЦигай х §Бентхаймер в сравнении с ичигайскими выме по валовому привесу на 0,54 кг, среднесуточному - на 8,8 г, индекс туши - на 1,06\%, однородность туши - на 2,32\% и на 4,61\% $(P \leq 0,05)$ - пропорциональность туши, масса парной туши - на 0,44 к2, масса охлажденной туши выше на 1,15 кг (3,8\%), убойный выход - на 47,61\%, а у чистопородных ичиаайских на 2,24\% ниже - 45,37\%. Количество белка и коллагена в мясе было одинаковым, а у помесных

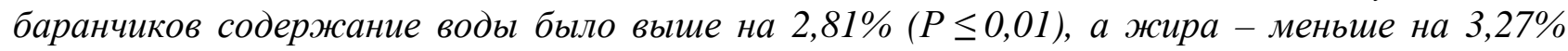
$(P \leq 0,01)$. Из полученных данных следует, что энергия роста, основные показатели по мясной

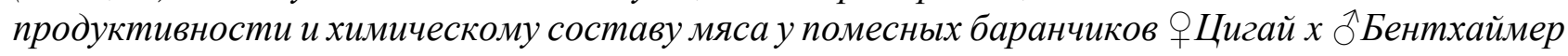
на определенный процент выше и лучше по отношению к чистопородным цигайским.

Ключевые слова: баранчики, живая масса, привес, индексы, туши, мясная продуктивность, коэффициент мясности

\section{MEAT PRODUCTIVITY OF TSIGAY SHEEP AND THEIR HYBRID WITH BENTHEIMER BREED}

P. I. Lyutskanov, O. A. Mashner

Scientific and Practical Institute of Biotechnologies in Zootechny and Veterinary Medicine, (Maksimovka, Moldova)

The article is devoted to the study of the meat productivity of the crossbreed lambs of the first generation $Q$ Tsigay $x{ }^{\lambda}$ Benthaymer in comparison with the Tsigay local population. It was carried outthe control of growinglambs with subsequent slaughter at 6 months of age. Were taken measurements of carcasses and calculated indices. For calculating the meat coefficient and obtaining an average sample of meat with the purpose of studying its chemical composition, was performed a sort cut with a boning of the right halves from all the hammered lambs. At the cross-breed lambs Q Tsigayx ${ }^{\Uparrow}$ Bentheimer, in comparison with the Tsigay, is higher by the gross weight gain by $0.54 \mathrm{~kg}$, the average daily by $8.8 \mathrm{~g}$. The carcass index is by $1.06 \%$, the carcass uniformity is by $2.32 \%$ and by $4.61 \%(P \leq 0,05)$ proportionality of the carcass.The weight of the paired carcass is by $0.44 \mathrm{~kg}$, the mass of the chilled carcass is by $1.15 \mathrm{~kg}(3.8 \%)$ higher. The slaughter yield is $47.61 \%$, and at purebred Tsigay, by $2.24 \%$ lower - $45.37 \%$. The amount of protein and collagen in the meat is the same, while at the crossbred lambs the water content is higher by $2.81 \%(P \leq 0.01)$ and fat is lower by $3.27 \%(P \leq 0.01)$. From the data obtained, it follows that the energy of growth, the main indicators on meat productivity and chemical composition of meat at crossbred lambs ${ }_{+}$Tsigay $x{ }^{\wedge}$ Bentheimeris higher for a certain percentage and better in relation to purebred Tsigay.

Keywords: lambs, live weight, weight gain, indices, carcasses, meat productivity, coefficient of meat

\section{М'ЯСНА ПРОДУКТИВНІСТЬ ЦИГАЙСЬКИХ ОВЕЦЬ ТА ЇХ ПОМІСІ 3 ПОРОДОЮ БЕНТХАЙМЕР}

\section{П. І. Люцканов, О. А. Машнер}

Науково-практичний інститут біотехнологій в зоотехнії і ветеринарній медицині (Максимівка, Молдова)

Стаття присвячена вивченню м'ясної продуктивності помісних баранців першого поко-

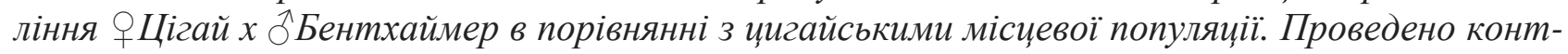
рольне вирощування бараниів з подальшим забоєм в 6-місячному віиі. Взяті проміри туш і розраховані індекси. Для розрахунку коефіцієнта м'ясності і отримання середньої проби м'яса 3 метою вивчення його хімічного складу була проведена сортова разрубка з обвалкой правих напівтуш від всіх забитих баранців. У помісних баранців о Цігай х Ј̄ Бентхаймер в порівнянні з ичгайськими вище по валовому приросту ваги на 0,54 кг, середньодобовим приростом - на

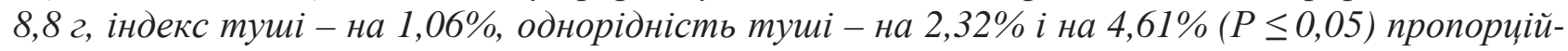
ність туші, маса парної туші на 0,44 кг, маса охолодженої туші вище на 1,15 кг (3,8\%), забійний вихід - 47,61\%, а у чистопородних ичигайських на 2,24\% нижче - 45,37\%. Кількість білка і колагену в м'ясі було однаковим, а у помісних баранців вміст води був вищим на 2,81\% $(P \leq 0,01)$, а жиру-менше на 3,27\% $(P \leq 0,01)$. 3 отриманих даних випливає, щзо енергія росту, 
основні показники по м'ясної продуктивності і хімічним складом м'яса у помісних баранців

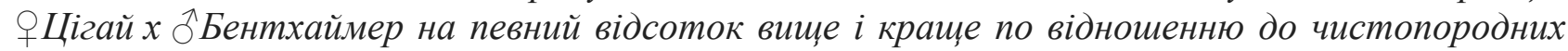
циигайських.

Ключові слова: баранчики, жива маса, приріст, індекси, туші, м'ясна продуктивність, коефіцієнт м'ясності

Введение. В Республике Молдова основная роль отрасли овцеводства - обеспечение населения традиционными продуктами питания, такими как брынза и баранина, которые глубоко вошли в быт как национальная пища и пользуются высоким спросом на рынке. Поэтому дальнейшее наращивание объемов их производства является важной социальной экономической задачей [1].

В 2007 и 2009 годах коллективом авторов созданы два новых типа овец: Молдавский тип цигайских овец шерстно-мясо-молочного направления продуктивности и Молдавский тип каракульских овец смушково-мясо-молочного направления продуктивности.

Минимальные требования молдавского типа цигайских овец предусматривают получение 95-105 литров молока за лактацию, что выше по сравнению с местным шерстно-молочным типом, но не удовлетворяют потребности и экономически мало рентабельно. В связи с этим, в последние годы завозятся импортные молочные породы овец - Бентхаймер, Остфризская, Лакон, Ассаф для чистопородного разведения и скрещивания с местными овцами. Учитывая природно-климатические условия чистопородные овцы не полностью реализуют свой генетический потенциал и сохранность низкая как у взрослого поголовья, так и у молодняка.

Начиная с 2012 года проводится скрещивание цигайских овцематок с баранами-производителями породы Бентхаймер. У полученных помесных животных изучена молочная продуктивность за полную лактацию, которая составила 121 литр, что на 16-26 литров выше минимальных требований стандарта.

Наряду с повышением молочной продуктивности стоит задача и об увеличении производства мяса на овцематку. Мясо овец имеет ряд отличительных особенностей по сравнению с мясом других сельскохозяйственных животных и пользуется большим спросом у населения. Мясная продуктивность овец характеризуется величиной живой массы, выходом туши, убойной массой и убойным выходом, соотношением мышц, жира и костей, коэффициентом мясности и другими показателями [2-4].

Цель исследований - изучение мясной продуктивности помесных баранчиков первого поколения фЦигай х §ૌБентхаймер в сравнении с цигайскими местной популяции.

Материалы и методы исследований. Исследования проводились на баранчиках цигайской породы местной популяции и помесей первого поколения фЦигай х $\precsim$ Бентхаймер, принадлежащих экспериментально-технологической станции «Максимовка». В четырех-месячном возрасте были отобраны баранчики-аналоги по живой массе при рождении, отъеме от матерей в 3-3,5 месяцев и перед постановкой на опыт. В течении 62 дней проведен контрольный откорм, взяты промеры тела и рассчитаны индексы телосложения в начале и конце опыта [5]. В конце опыта рассчитан прирост живой массы и среднесуточные привесы [6]. В соответствии с методическими рекомендациями [7] проведен контрольный убой по 5 голов из каждой группы. Взяты промеры туш и рассчитаны индексы [8]. На приборе Cagle lab's изучен химический состав мяса средней пробы. Статистическая обработка результатов опыта для оценки значимости различий состояла в группировке материала, вычислении средней арифметической (M), ошибки (m), критерия достоверности [9].

Результаты исследований. Молочную породу овец Бентхаймер использовали в скрещивании с местными цигайскими с целью повышения молочной продуктивности и сравнения, не ухудшились ли мясные качества. В наших исследованиях поставлена задача по изучению мясных качеств баранчиков цигайской породы и помесей первого поколения ФЦигай х $\precsim$ Бентхаймер. При постановке на опыт по пять голов баранчиков в каждой группе средний возраст составил 117-115 дней. Живая масса помесных баранчиков при рождении была 
на 0,68 кг больше чистопородных $(\mathrm{P} \leq 0,05)$, а при отбивке живая масса цигайских баранчиков была выше на 3,02 кг, разница достоверна $(\mathrm{P} \leq 0,001)$. Живая масса цигайских баранчиков по отношению к баранчикам ф Цигай х §̋Бентхаймер в начале опыта была больше на 1,1 кг, в конце опыта - на 0,56 кг. За период контрольного выращивания у помесных баранчиков валовый привес и среднесуточный был выше по отношению к цигайским чистопородным соответственно на 0,54 кг и 8,8 г за счет эффекта гетерозиса. Все это показывает, что энергия роста помесных баранчиков цигайским (табл. 1).

\begin{tabular}{|c|c|c|c|c|c|c|c|}
\hline \multirow{3}{*}{ Порода/Помеси } & \multirow{3}{*}{$\begin{array}{l}\text { Воз- } \\
\text { раст, } \\
\text { дней }\end{array}$} & \multirow{2}{*}{\multicolumn{4}{|c|}{ Живая масса }} & \multirow[b]{3}{*}{ Привес } & \multirow{3}{*}{$\begin{array}{l}\text { Средне-суточ- } \\
\text { ный привес, г }\end{array}$} \\
\hline & & & & & & & \\
\hline & & $\begin{array}{c}\text { при рожде- } \\
\text { нии } \\
\end{array}$ & при отбивке & $\begin{array}{c}\text { в начале } \\
\text { опыта }\end{array}$ & $\begin{array}{c}\text { в конце } \\
\text { опыта }\end{array}$ & & \\
\hline Цигайская порода & 117 & $4,48 \pm 0,21$ & $\begin{array}{c}23,78 \pm 0,41 \\
* * *\end{array}$ & $27,48 \pm 0,42$ & $44,20 \pm 0,98$ & $16,72 \pm 0,85$ & $269,80 \pm 13,71$ \\
\hline $\begin{array}{l}\text { ФЦигай х }{ }^{\Uparrow} \text { Бентхай } \\
\text { мер }(50 \%)\end{array}$ & 115 & $5,16 \pm 0,09 *$ & $20,76 \pm 0,89$ & $26,38 \pm 2,08$ & $43,64 \pm 2,88$ & $17,26 \pm 1,21$ & $278,60 \pm 19,48$ \\
\hline
\end{tabular}

Примітка. $* P \leq 0,05 ; * * * P \leq 0,001$

В обеих исследуемых группах ягнят в начале и в конце опыта были взяты промеры тела и рассчитаны индексы телосложения (табл. 2). В начале опыта по всем индексам телосложения у помесных баранчиков показатели находились в пределах от 0,38 до 4,34\%. В конце опыта наблюдалась такая же тенденция - от 0,32 до 2,24\%, за исключением грудного индекса, который у помесей ками цигайской породы.

2. Индексы телосложения опытных баранчиков (\%)

\begin{tabular}{|c|c|c|c|c|c|c|}
\hline \multirow{2}{*}{ Показатель } & \multicolumn{3}{|c|}{ Цигайская порода } & \multicolumn{3}{|c|}{ 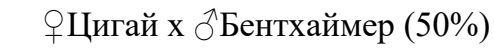 } \\
\hline & $\mathrm{M} \pm \mathrm{m}$ & $\sigma$ & $\mathrm{Cv}, \%$ & $\mathrm{M} \pm \mathrm{m}$ & $\sigma$ & $\mathrm{Cv}, \%$ \\
\hline \multicolumn{7}{|c|}{ в начале опыта } \\
\hline Растянутости & $102,35 \pm 1,15$ & 2,57 & 2,51 & $101,96 \pm 2,07$ & 4,63 & 4,55 \\
\hline Поперечный & $38,45 \pm 1,43$ & 3,19 & 8,31 & $37,01 \pm 0,62$ & 1,38 & 3,74 \\
\hline Массивности & $130,07 \pm 2,89$ & 6,46 & 4,97 & $128,27 \pm 3,46$ & 7,74 & 6,04 \\
\hline Грудной & $85,07 \pm 1,42$ & 3,18 & 3,74 & $83,36 \pm 0,59$ & 1,33 & 1,59 \\
\hline Сбитости & $127,21 \pm 3,77$ & 8,43 & 6,63 & $125,84 \pm 2,83$ & 6,33 & 5,03 \\
\hline Костистости & $13,71 \pm 0,19$ & 0,42 & 3,09 & $13,14 \pm 0,45$ & 1,02 & 7,73 \\
\hline \multicolumn{7}{|c|}{ в конце опыта } \\
\hline Растянутости & $111,51 \pm 1,62$ & 3,63 & 3,25 & $110,80 \pm 1,72$ & 3,84 & 3,46 \\
\hline Поперечный & $41,32 \pm 1,16$ & 2,59 & 6,27 & $41,19 \pm 1,53$ & 3,42 & 8,30 \\
\hline Массивности & $146,34 \pm 2,94$ & 6,57 & 4,49 & $145,21 \pm 2,19$ & 4,90 & 3,37 \\
\hline Грудной & $80,20 \pm 1,37$ & 3,06 & 3,82 & $81,72 \pm 2,43$ & 5,44 & 6,66 \\
\hline Сбитости & $131,34 \pm 3,34$ & 7,47 & 5,69 & $131,16 \pm 2,72$ & 6,08 & 4,64 \\
\hline Костистости & $13,29 \pm 0,38$ & 0,84 & 6,32 & $13,00 \pm 0,35$ & 0,78 & 6,02 \\
\hline
\end{tabular}

В соответствии с программой проведения контрольного выращивания баранчиков опытных групп по истечении 62 дней и голодной выдержки в течении 24 часов были взвешены опытные ягнята и проведен контрольный убой. Предубойная живая масса цигайских баранчиков составила 39,54 кг и помесных ФЦигай х §ึБентхаймер - 39,13 кг или на 0,41 кг ниже.

После проведения контрольного убоя были взяты промеры у туш и рассчитаны семь индексов (табл. 3). 
3. Индексы туш баранчиков (\%)

\begin{tabular}{|l|c|c|c|c|c|c|}
\hline \multirow{2}{*}{ Показатель } & \multicolumn{3}{|c|}{ Цигайская порода } & \multicolumn{3}{c|}{ ФЦигай х Ј`Бентхаймер (50\%) } \\
\cline { 2 - 8 } & $\mathrm{M} \pm \mathrm{m}$ & $\sigma$ & $\mathrm{Cv}, \%$ & $\mathrm{M} \pm \mathrm{m}$ & $\sigma$ & $\mathrm{Cv}, \%$ \\
\hline Индекс туши & $34,47 \pm 0,30$ & 0,68 & 1,96 & $35,53 \pm 0,77$ & 1,72 & 4,83 \\
\hline Индекс окорока & $55,28 \pm 1,45$ & 3,24 & 5,87 & $52,07 \pm 0,76$ & 1,69 & 3,25 \\
\hline Компактность туши & $99,10 \pm 2,14$ & 4,78 & 4,82 & $96,22 \pm 1,01$ & 2,25 & 2,34 \\
\hline Однородность туши & $88,96 \pm 4,48$ & 10,02 & 11,26 & $91,28 \pm 1,87$ & 4,18 & 4,58 \\
\hline Развитие окорока & $151,33 \pm 4,85 * *$ & 10,85 & 7,17 & $131,59 \pm 2,58$ & 5,76 & 4,38 \\
\hline Глубина груди & $36,07 \pm 0,80$ & 1,79 & 4,95 & $35,61 \pm 0,64$ & 1,42 & 4,03 \\
\hline Пропорциональность окорока & $60,19 \pm 1,32$ & 2,95 & 4,89 & $64,80 \pm 1,49 *$ & 3,33 & 5,14 \\
\hline
\end{tabular}

Примітка. $* P \leq 0,05 ; * * P \leq 0,01$.

Некоторые индексы у цигайских баранчиков были выше по отношению к помесям фЦигай х ठొБентхаймер: на 3,21\% индекс окорока, 2,88 - компактность туши, $19,74(\mathrm{P} \leq 0,01)$ - развитие окорока и 0,46 - глубина груди. По остальным индексам у помесных ягнят выше на 1,06 индекс туши, 2,32 - однородность туши и 4,61 $(\mathrm{P} \leq 0,05)$ - пропорциональность туши.

Масса парной туши у помесей была выше в сравнении с чистопородными цигайскими на 0,44 кг, у помесных баранчиков и масса охлажденной туши - выше на 1,15 кг (3,8\%). Сравнивая убойный выход, следует отметить, что у помесных он составил 47,61\%, а у чистопородных цигайских на 2,24\% ниже - 45,37\% (табл. 4).

4. Мясная продуктивность баранчиков $(M \pm m)$

\begin{tabular}{|c|c|c|}
\hline Показатель & Цигайская порода & $\begin{array}{c}\text { фЦигай х ठొБентхаймер } \\
(50 \%)\end{array}$ \\
\hline Предубойная живая масса, кг & $39,54 \pm 1,02$ & $39,13 \pm 3,02$ \\
\hline Масса парной туши, кг & $19,42 \pm 0,51$ & $19,86 \pm 1,70$ \\
\hline Масса охлажденной туши, кг (12 часов) & $17,48 \pm 0,50$ & $18,63 \pm 1,69$ \\
\hline Вес почек с околопочечным жиром & $0,46 \pm 0,03$ & $0,39 \pm 0,05$ \\
\hline Убойная масса & $17,94 \pm 0,50$ & $18,63 \pm 1,69$ \\
\hline Убойный выход, \% & $45,37 \pm 1,74$ & $47,61 \pm 0,83$ \\
\hline $\begin{array}{l}\text { Вес полутуши, кг, } \\
\text { из которых: }\end{array}$ & $9,074 \pm 0,25$ & $9,426 \pm 0,83$ \\
\hline - мясо & $7,018 \pm 0,23$ & $7,178 \pm 0,72$ \\
\hline - кости & $1,996 \pm 0,08$ & $2,192 \pm 0,13$ \\
\hline - жир & $0,060 \pm 0,11$ & $0,050 \pm 0,02$ \\
\hline - коэффициент мясности & 3,52 & 3,27 \\
\hline $\begin{array}{l}\text { Химический состав мяса, \% } \\
\text { - вода } \\
\text { - жир } \\
\text { - белок } \\
\text { - коллаген }\end{array}$ & $\begin{array}{c}63,81 \pm 0,35 \\
18,05 \pm 0,41 * * \\
16,23 \pm 0,10 \\
1,44 \pm 0,03\end{array}$ & $\begin{array}{c}66,62 \pm 0,58^{* *} \\
14,78 \pm 0,77 \\
16,55 \pm 0,20 \\
1,45 \pm 0,04\end{array}$ \\
\hline
\end{tabular}

Примітка. ${ }^{* *} P \leq 0,01$

Для расчета коэффициента мясности и получения средней пробы с целью изучения химического состава мяса была проведена обвалка правых полутуш, полученных при сортовой разрубке пяти туш с каждой опытной группы. Коэффициент мясности у цигайских баранчиков составил 3,52, то есть на один килограмм костей приходится 3,52 кг мяса. У помесей оЦигай х §ॅБентхаймер он составил 3,27, что на 0,25 меньше по сравнению с баранчиками цигайской породы. По химическому составу мяса в обеих группах количество белка и коллагена было одинаковым. У помесных баранчиков содержание воды было выше на 2,81\% ( $\mathrm{P} \leq 0,01)$, а жира - меньше на 3,27\% (P $\leq 0,01)$, то есть их мясо более постное. В завершении следует отметить, что основные показатели по мясной продуктивности и химическому составу мяса у помесных баранчиков породным цигайским. 
Выводы. Помесные баранчики ф Цигай х §ББентаймер по сравнению с цигайскими были выше по валовому привесу на 0,54 кг, среднесуточному - на 8,8 г, индекс туши - на $1,06 \%$, однородность туши - на 2,32\% и на 4,61\% (P $\leq 0,05)$ - пропорциональность туши, масса парной туши - на 0,44 кг, масса охлажденной туши - выше на 1,15 кг $(3,8 \%)$, убойный выход - 47,61\%, а у чистопородных цигайских на 2,24\% ниже $-45,37 \%$. Количество белка и коллагена в мясе одинаковым, а у помесных баранчиков содержание воды было выше на 2,81\% $(\mathrm{P} \leq 0,01)$, а жира было меньше на $3,27 \%(\mathrm{P} \leq 0,01)$.

Из полученных данных следует, что энергия роста, основные показатели по мясной про-

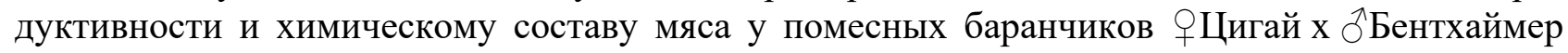
были выше и лучше по отношению к чистопородным цигайским.

\section{БИБЛИОГРАФИЯ}

1. Люцканов, П. И. Молочная и мясная продуктивность овец нового типа «Цигай Александерфельд» / П. И. Люцканов // Журнал Agricultura Moldovei. - 2008. - № 1. - С. 20-22.

2. Мясная продуктивность овец и факторы, её определяющие / В. В. Абонеев, Ю. Д. Квитко, А. В. Килпа, Б. Т. Абилов, В. В. Марченко, Д. И. Абонеев, А. А. Омаров А. М. Яковенко, Н. И. Ефимова. - Ставрополь, 2011. - 153 с.

3. Жиряков, А. М. Промышленное скрещивание овец / А. М. Жиряков, Р. С. Хамицаев. Москва : Агропромиздат. - 1986. - 112 с.

4. Яцкин, В. И. Повышение эффективности производства баранины / В. И. Яцкин. Москва, 2004. - 423 с.

5. Красота, В. Ф. Разведение сельскохозяйственных животных / В. Ф. Красота, В. Т. Лобанов. - Москва : Колос. $-1976 .-416$ с.

6. Рекомендации по технологии производства продукции овцеводства в Республике Молдова. - Кишинев : Молдагроинформреклама. - 1992. - 85 с.

7. Изучение мясной продуктивности овец : метод. рек. - Москва, 1978. - 45 с.

8. Taftă, V. Producţia, ameliorarea şi reproducţia ovinelor / V. Taftă, I. Vintilă, S. Zamfirescu // Ed. CERES. Bucureşti. 1997. - 518 p.

9. Плохинский, Н. И. Руководство по биометрии для зоотехников / Н. И. Плохинский. Москва, 1969. - 256 с.

\section{REFERENCES}

1. Ljuckanov, P. I. 2008. Molochnaja i mjasnaja produktivnost' ovec novogo tipa «Cigaj Aleksanderfel'd»-Dairy and meat productivity of new type of sheep "Tsigai Alexanderfeld". Zhurnal Agricultura Moldovei - Journal Agricultura Moldovei. 1:20-22 (in Moldovan).

2. Aboneev, V. V., Ju. D. Kvitko, A. V. Kil'pa, B. T. Abilov, V. V. Marchenko, D. I. Aboneev, A. A. Omarov, A. M. Jakovenko and N. I. Efimova. 2011. Mjasnaja produktivnost' ovec i faktory ejo opredeljajushhie - Meat productivity of sheep and its determinant. Stavropol'. 153 (in Russian).

3. Zhirjakov, A. M., and R. S. Hamicaev. 1986. Promyshlennoe skreshhivanie ovec - Industrial crossing of sheep. Moskva, Agropromizdat, 112 (in Russian).

4. Jackin, V. I. 2004. Povyshenie effektivnosti proizvodstva baraniny - Improving the production of lamb. Moskva. 423 (in Russian).

5. Krasota, V. F. and V. T. Lobanov. 1976. Razvedenie sel'skohozjajstvennyh zhivotnyh Breeding of farm animals. Moskva, Kolos. 416 (in Russian).

6. Rekomendacii po tehnologii proizvodstva produkcii ovcevodstva v Respublike Moldova Recommendations on the technology of production of sheep products in the Republic of Moldova. 1992. Kishinev, Moldagroinformreklama. 85 (in Moldovan).

7. 1978. Metodicheskie rekomendacii «Izuchenie mjasnoj produktivnosti ovec»-Methodical recommendations "Studying the meat productivity of sheep". Moskva, 45. (in Russian).

8. Taftă, V., I. Vintilă, and S. Zamfirescu. 1997. Producţia, ameliorarea şi reproducţia ovinelor. Ed. CERES. Bucureşti. 518 (in Romanian).

9. Plohinskij, N. I. 1969. Rukovodstvo po biometrii dlja zootehnikov - Biometrics manual for livestock experts. Moskva. 256 (in Russian). 